\title{
Soil Physical Quality Indicators and Refinement of the Evaluation Method through the $\mathrm{S}_{\text {relative }}$
}

\author{
Thiago Leite Alencar ${ }^{1}$, Arilene Franklin Chaves ${ }^{2}$, Alcione Guimarães Freire ${ }^{1}$, Márcio Godofrêdo Rocha Lobato ${ }^{1}$, \\ Ícaro Vasconcelos Nascimento ${ }^{1} \&$ Jaedson Claúdio Anunciato Mota ${ }^{1}$ \\ ${ }^{1}$ Departamento de Ciências do Solo, Universidade Federal do Ceará, Brazil \\ ${ }^{2}$ Instituto Federal de Educação, Ciência e Tecnologia do Ceará, Brazil \\ Correspondence: Márcio Godofrêdo Rocha Lobato, Departamento de Ciências do Solo, Universidade Federal do \\ Ceará, Brazil. E-mail: marciogrl@hotmail.com
}

Received: November 28, 2017

Accepted: January 16, 2018

Online Published: February 15, 2018

doi:10.5539/jas.v10n3p151

URL: https://doi.org/10.5539/jas.v10n3p151

\begin{abstract}
This study aimed to verify the efficiency of indicators of measure of physical attributes' alterations and to refine the $S_{\text {relative }}$ determination method in order to increase its sensitivity to soil physical alterations. Soils under Ficus carica L. cultivation (with $0,20,40$ and $60 \%$ of liquid bovine biofertilizer in the irrigation depth) and under forest were used. Parameters evaluated included soil granulometry, soil bulk and particle density, soil water retention curve (SWRC), porosity and the indices $\mathrm{S}$ and $\mathrm{S}_{\text {relative. }}$ The experimental design was completely randomized with four replicates. For $\mathrm{S}_{\text {relative }}$ refinement, with the SWRC containing only textural porosity, the soil was dispersed in water and with the addition of $1 \mathrm{~N}$ sodium hydroxide (with and without removal of sodium through washing). An ANOVA was performed for 0, 20, 40 and 60\% of biofertilizer in 0-10, 10-20 and 20-30 layers; Dunnett test was

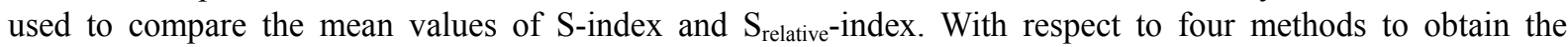

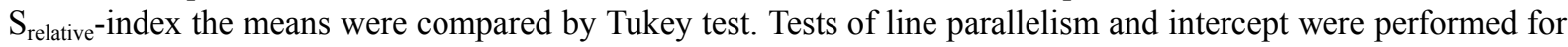
the regressions between each of the soil physical variables and $S_{\text {relative-index obtained. It was found that } S \text { and }}$ $S_{\text {relative }}$ indices were sensitive to soil physical alterations caused by the application of the biofertilizer; Srelative-index was sensitive to variation in soil bulk density and total porosity and the $S_{\text {relative-index obtained from }}$ the method of soil dispersion in water is more sensitive to soil physical alterations in comparison to $S_{\text {relative-index }}$ obtained through ADFE.
\end{abstract}

Keywords: organic matter, soil physics, soil and environment

\section{Introduction}

Soil quality has become a theme of interest to researchers concerned with the protection of the soil and the sustainability of the agricultural systems. Initially, efforts were made to define soil quality and later transform such concept into something measurable (Armenise et al., 2013).

In soil science, various approaches about the concept of quality have been used by researchers and most of them are based on Larson and Pierce (1994)'s definition of soil quality as a combination of physical, chemical and biological properties that provide the means for both plant and animal production, as well as to regulate the water flow in the environment and serve as an environmental filter in the attenuation and degradation of environmentally damaging or dangerous components. For Villamil et al. (2008), soil quality is a multidimensional concept, in which many studies are involved, in combination or individually, in order to improve the understanding of the dynamics of the system.

Soil quality cannot be determined directly, but can be constantly monitored through the quantification of alterations in its attributes resulting from use and management systems (Neves et al., 2007; Obade \& Lal, 2016a). Monitoring soil quality is a promising component to be used in management strategies of agricultural soils (Ripoche et al., 2010).

However, it should be pointed out that the simplification of information about soil quality may result in inconsistent conclusions, which can lead to damages to the studied system, since some of the analyzed attributes are subjective and insufficient to represent a complex environment that plays various functions, like the soil 
(Obade \& Lal, 2016a, 2016b). Thus, the most sensitive attributes to changes in soil management practices are the most adequate to be used as indicators (Arshad \& Martin, 2002).

In this perspective, researchers have attempted to identify, select and attribute quantitative values to quality indicators that best represent the performance of certain functions of the soil. Among the various indicators, an index of evaluation of soil structure- $\mathrm{S}_{\text {relative }}$-index — derived from the S-index proposed by Dexter in 2004, was presented by Freire (2012). The results observed so far have been promising; however, it was verified in Freire (2012), Alves (2013), and Assis Júnior et al. (2016) the incomplete individualization of the particles to obtain the soil water retention curve reference. Thus, the $S_{\text {relative }}$-index requires refinement to improve its sensitivity to physical changes imposed to the soil.

In this context, the study was based on the following hypotheses: 1) soil physical alterations can be assessed by

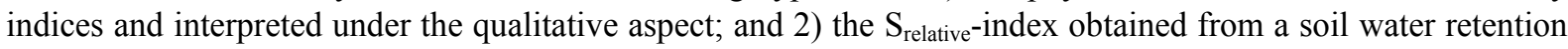
curve determined as close as possible to the textural porosity (reference curve) is more sensitive to soil physical

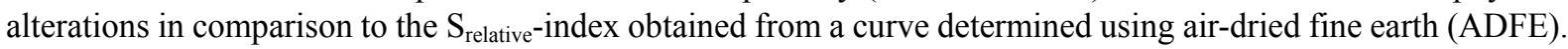
Therefore, this study aimed to verify the efficiency of indicators of the measure of physical attributes alterations and to refine the $\mathrm{S}_{\text {relative }}$-index determination method in order to increase its sensitivity to soil physical alterations.

\section{Material and Methods}

\subsection{Studied Area}

The studied area is located in the Apodi Plateau, at the Unit of Teaching, Research and Extension (UEPE), one of the physical units of the Federal Institute of Education, Science and Technology (IFCE - Campus of Limoeiro do Norte), situated in the municipality of Limoeiro do Norte-CE, Brazil, at an altitude of $145 \mathrm{~m}$. The experimental area, cultivated with fig (Ficus carica L.), has in its center the geographic coordinates of $5^{\circ} 10^{\prime} 57.64^{\prime \prime} \mathrm{S}$ and $38^{\circ} 0^{\prime} 45.97^{\prime \prime} \mathrm{W}$. The secondary forest taken as a reference is located $400 \mathrm{~m}$ away from the cultivated area. The soil of the experimental area is a Cambissolo Háplico (Embrapa, 2013). Some soil physical attributes are shown in Table 1.

Table 1. Soil physical characteristics

\begin{tabular}{|c|c|c|c|c|c|c|}
\hline \multirow{2}{*}{ Use and management system } & \multirow{2}{*}{ Layers } & \multicolumn{3}{|c|}{ Grain size } & \multirow{2}{*}{ Natural clay } & \multirow{2}{*}{ Textural class } \\
\hline & & Sand & Silt & Clay & & \\
\hline & --- cm --- & ----- & - & $\mathrm{kg}^{-1}-$ & $-\overline{----}$ & \\
\hline \multirow[t]{3}{*}{ Biofertilizer $(0 \%)$} & $0-10$ & 539 & 269 & 192 & 131 & Sandy loam \\
\hline & $10-20$ & 518 & 252 & 230 & 145 & Sandy clay loam \\
\hline & $20-30$ & 466 & 254 & 280 & 184 & Sandy clay loam \\
\hline \multirow[t]{3}{*}{ Biofertilizer $(20 \%)$} & $0-10$ & 517 & 288 & 195 & 126 & Sandy loam \\
\hline & $10-20$ & 508 & 265 & 227 & 163 & Sandy clay loam \\
\hline & $20-30$ & 460 & 271 & 269 & 187 & Sandy clay loam \\
\hline \multirow[t]{3}{*}{ Biofertilizer $(40 \%)$} & $0-10$ & 525 & 281 & 194 & 143 & Sandy loam \\
\hline & $10-20$ & 495 & 264 & 241 & 156 & Sandy clay loam \\
\hline & $20-30$ & 475 & 250 & 275 & 188 & Sandy clay loam \\
\hline \multirow[t]{3}{*}{ Biofertilizer $(60 \%)$} & $0-10$ & 542 & 261 & 197 & 158 & Sandy loam \\
\hline & $10-20$ & 488 & 244 & 268 & 152 & Sandy clay loam \\
\hline & $20-30$ & 460 & 257 & 283 & 193 & Sandy clay loam \\
\hline \multirow[t]{3}{*}{ Forest } & $0-10$ & 748 & 156 & 96 & 50 & Sandy loam \\
\hline & $10-20$ & 625 & 154 & 221 & 132 & Sandy clay loam \\
\hline & $20-30$ & 507 & 168 & 325 & 186 & Sandy clay loam \\
\hline
\end{tabular}

For particle-size distribution analysis, clay $(\leq 0.002 \mathrm{~mm})$ content was determined through the pipette method, sand $(2.00$ to $>0.053 \mathrm{~mm})$ content through sieving and silt $(0.053$ to $>0.002 \mathrm{~mm})$ content was the difference between sand and clay fractions. Clay dispersed in water was determined using the same method adopted for particle-size distribution, but without the chemical dispersant.

\subsection{Experimental Procedure}

The experiment was carried out in an open field, cultivated with fig, which was applied different rates of biofertilizer. The experiment began in October 2010. The biofertilizer applied to the soil was produced through 
anaerobic process in a $200 \mathrm{~L}$-plastic container. A hose was adapted and connected to the lid and its other tip was submerged in a container with water at the height of $20 \mathrm{~cm}$ for the outlet of gases. The proportion used for the production of the biofertilizer was 1 volume of fresh bovine manure for 1 volume of water fermented for 30 days.

The rates of the biofertilizer were formulated with the following proportions: T0 100\% of water; T1 for $20 \%$ of biofertilizer and $80 \%$ of water; T2 for $40 \%$ of biofertilizer and $60 \%$ of water; and T3 for $60 \%$ of biofertilizer and $40 \%$ of water. Three liters of biofertilizer were applied to the soil per plant and twice per month from October 2010 to August 2012, totaling 23 months during the 4 crop cycles.

At the end of the experiment, the organic matter added to the soil through the biofertilizer at $20 \%, 40 \%$ and $60 \%$ were approximately $0.41 \mathrm{~kg}, 0.82 \mathrm{~kg}$ and $1.24 \mathrm{~kg}$, respectively, per area available to the plant. Samples of the biofertilizer were analyzed in the Soil, Water and Plant Tissues (LABSAT) Laboratory of the IFCE for chemical characterization (Table 2).

For soil quality evaluation, five soil treatments were considered including, under fig cultivation, one treatment of each of the applications of $20 \%, 40 \%$ and $60 \%$ of liquid bovine biofertilizer in the irrigation depth, $100 \%$ water i.e. without biofertilizer application and one without biofertilizer but under natural vegetation. Each of the 5 treatments was applied at each of the three following soils depths: $0-10 \mathrm{~cm}, 10-20 \mathrm{~cm}$ and $20-30 \mathrm{~cm}$ (Table 2). The experimental was a completely randomized design with four replicates. Disturbed and undisturbed soil samples were collected using an Uhland sampler, in steel rings with $0.05 \mathrm{~m}$ of height and $0.05 \mathrm{~m}$ of diameter. In the laboratory, soil samples were analyzed for granulometry, soil bulk and particle density, soil water retention curve, total porosity, $\mathrm{S}$-index and $\mathrm{S}_{\text {relative-index. }}$

Table 2. Chemical characteristics of different rates of bovine biofertilizer

\begin{tabular}{|c|c|c|c|c|c|c|c|c|c|c|c|c|}
\hline \multirow{2}{*}{ Samples } & \multicolumn{6}{|c|}{ Macronutrients } & \multicolumn{6}{|c|}{ Micronutrients } \\
\hline & $\mathrm{N}$ & $\mathrm{P}$ & $\mathrm{K}$ & $\mathrm{Ca}$ & $\mathrm{Mg}$ & $\mathrm{S}$ & $\mathrm{Fe}$ & $\mathrm{Zn}$ & $\mathrm{Cu}$ & $\mathrm{Mn}$ & $\mathrm{B}$ & $\mathrm{Na}$ \\
\hline & \multicolumn{6}{|c|}{ - } & \multicolumn{6}{|c|}{ - } \\
\hline Pure $(100 \%)$ & 0.78 & 0.73 & 1.19 & 0.59 & 0.28 & 0.21 & 73.04 & 5.88 & 2.04 & 9.32 & 1.62 & 175 \\
\hline $20 \%$ & 0.16 & 0.15 & 0.25 & 0.12 & 0.06 & 0.06 & 14.60 & 1.17 & 0.40 & 1.86 & 0.32 & 35 \\
\hline $40 \%$ & 0.31 & 0.29 & 0.49 & 0.24 & 0.11 & 0.08 & 29.21 & 2.35 & 0.82 & 3.72 & 0.48 & 70 \\
\hline \multirow[t]{2}{*}{$60 \%$} & 0.47 & 0.44 & 0.68 & 0.35 & 0.17 & 0.13 & 43.82 & 3.52 & 1.22 & 5.59 & 0.97 & 105 \\
\hline & \multicolumn{3}{|c|}{ E.C. $\left(\mathrm{dS} \mathrm{m}^{-1}\right)$} & \multicolumn{3}{|l|}{$\mathrm{C}(\%)$} & \multicolumn{3}{|l|}{$\mathrm{C} / \mathrm{N}$} & \multicolumn{3}{|l|}{$\mathrm{pH}$} \\
\hline Pure $(100 \%)$ & \multicolumn{3}{|l|}{7.05} & \multicolumn{3}{|l|}{1.08} & \multicolumn{3}{|l|}{13.8} & \multicolumn{3}{|l|}{7.78} \\
\hline $20 \%$ & \multicolumn{3}{|l|}{1.41} & \multicolumn{3}{|l|}{0.216} & \multicolumn{3}{|l|}{13.5} & \multicolumn{3}{|l|}{8.05} \\
\hline $40 \%$ & \multicolumn{3}{|l|}{2.82} & \multicolumn{3}{|l|}{0.432} & \multicolumn{3}{|l|}{13.9} & \multicolumn{3}{|l|}{8.29} \\
\hline $60 \%$ & \multicolumn{3}{|l|}{4.23} & \multicolumn{3}{|l|}{0.648} & \multicolumn{3}{|l|}{13.8} & \multicolumn{3}{|l|}{8.14} \\
\hline
\end{tabular}

\subsection{Analyses}

\subsubsection{Laboratory Analyses}

In the granulometric analyses, clay was determined through the pipette method, sand through sieving, and silt through the difference between clay and sand fractions (Gee \& Bauder, 1986). Soil particle density $\left(\rho_{p}\right)$ was determined through the volumetric flask method (Blake \& Hartge, 1986a) and soil bulk density $\left(\rho_{s}\right)$ using undisturbed samples, collected in cylinders with a known volume and dried at $105^{\circ} \mathrm{C}$ until constant mass (Blake \& Hartge, 1986b). Soil porosity was obtained by the equation:

$$
T P=\left[1-\left(\rho_{s} / \rho_{p}\right)\right]
$$

where, $T P$ is porosity $\left(\mathrm{m}^{3} \mathrm{~m}^{-3}\right)$, and $\rho_{p}$ and $\rho_{s}$ are in $\mathrm{kg} \mathrm{dm}^{-3}$.

In the determination of the soil water retention curve, the water content at saturation was considered as equal to soil porosity $(T P)$; for low tensions $(2,4,6,8$ and $10 \mathrm{kPa})$, the points were obtained using Haines' funnel. The other points $(33,100,300,700,1000$ and $1500 \mathrm{kPa})$ were obtained using Richards pressure plate apparatus (Klute, 1986). The curve was fit using the mathematical model proposed by van Genuchten (1980)'s Equation (2),

$$
\theta=\theta_{r}+\frac{\theta_{s}-\theta_{r}}{\left[1+(\alpha|\varphi|)^{n}\right]^{n}}
$$

where, $\theta_{r}$ and $\theta_{s}$ are, residual and saturation water contents $\left(\mathrm{m}^{3} \mathrm{~m}^{-3}\right)$, respectively, $\phi$ the soil water matric potential (kPa), $\alpha$ (scaler of $\phi$ ), $m$ and $n$ (related to the shape of the curve). The software SWRC, version 2.0, was used and 
the variables $\theta_{s}$ and $\theta_{r}$ were fixed with soil moisture values measured in the laboratory at saturation and at the tension of $1500 \mathrm{kPa}$, respectively. The parameters $\alpha, m$ and $n$ were fitted using the iterative method of Newton-Raphson, with no dependence between the parameters $m$ and $n$ (Dourado-Neto et al., 2000).

Based on the parameters of van Genuchten's equation, the slope at the inflection point (S-index) was determined according to the following equation (Dexter, 2004a):

$$
S=-n \cdot\left(u_{\text {sat }}-u_{r e s}\right) \cdot\left[1+\frac{1}{m}\right]^{-(1+m)}
$$

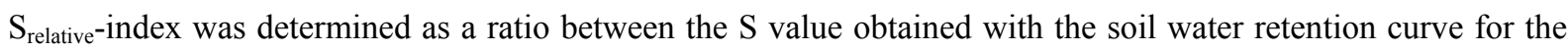
considered management and the $\mathrm{S}$ of the reference curve. The S-index used as reference was obtained through the water retention curve for the soil of the secondary forest, with a disturbed soil sample, using a sample of air-dried fine earth (ADFE), placed in rings with $0.05 \mathrm{~m}$ of height and $0.05 \mathrm{~m}$ diameter, which was prepared in such a way that the particles were normally arranged without the necessity to pre-establish a value of soil bulk density (Freire, 2012).

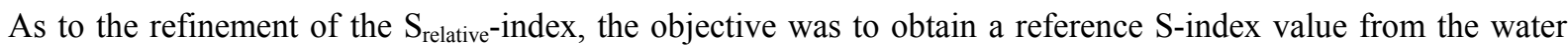
retention curve determined using soil with disturbed structure as close as possible to the textural porosity, since the perception of the studies of Freire (2012), Alves (2013), and Assis Júnior et al. (2016) is that the curve determined from the ADFE still contains part of its porosity associated with the microstructure. In the refinement process, the

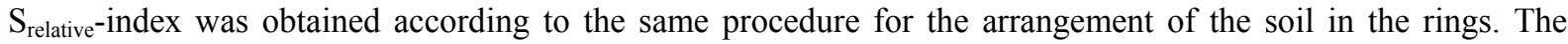
difference is that the material tested was dispersed in water then added $1 \mathrm{~N}$ sodium hydroxide (with and without subsequent washing for the removal of salts, particularly sodium). Dispersion was performed following the pipette method established by Gee and Bauder (1986). As previously mentioned, the dispersion aimed to arrange soil particles according to the textural porosity. After the process of chemical and physical dispersion, the samples containing sand, silt and clay in solution were dried in an oven at $45^{\circ} \mathrm{C}$ until constant mass.

After drying in the oven, the material was analyzed for the size distribution of the fractions. For comparison purposes, the analyses were performed using $20 \mathrm{~g}$ of ADFE, $20 \mathrm{~g}$ of material dispersed in water and $20 \mathrm{~g}$ of material dispersed with addition of $1 \mathrm{~N}$ sodium hydroxide (with and without subsequent washing). Each material was sieved through a set of five sieves $(1 \mathrm{~mm} ; 0.5 \mathrm{~mm} ; 0.25 \mathrm{~mm} ; 0.105 \mathrm{~mm}, 0.053 \mathrm{~mm}$ ), totaling six size classes ( $\leq$ $2 \mathrm{~mm}$ to $>1 \mathrm{~mm} ; \leq 1 \mathrm{~mm}$ to $>0.5 \mathrm{~mm} ; \leq 0.5 \mathrm{~mm}$ to $>0.25 \mathrm{~mm} ; \leq 0.25 \mathrm{~mm}$ to $>0.105 \mathrm{~mm} ; \leq 0.105 \mathrm{~mm}$ to $>0.053$ $\mathrm{mm} ; \leq 0.053 \mathrm{~mm})$.

After dispersion and analysis of distribution of the fractions according to the diameter, the material was used to generate the soil water retention curve and, from the curve, the $\mathrm{S}$ index value was obtained. As described in Freire

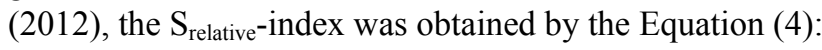

$$
S_{\text {relative }}=\frac{S_{\text {undisturbed sample }}}{S_{\text {disturbed sample }}}
$$

remembering that the values of $\mathrm{S}$, in both forms of soil structure, mathematically derived from equation (1), but replaced the volume-based moisture by the gravimetric moisture. The program Microsoft Excel ${ }^{\circledR}$ was used for data processing. The Kolmogorov-Smirnov test at 0.05 probability level was applied to verify data normality.

\subsubsection{Statistical Analyses}

The granulometric distribution data received statistical treatment using the microcomputer program PHI, developed by Jong van Lier and Vidal-Torrado (1992), which uses the statistical parameters of Folk and Ward (1957) to establish comparisons between the classes of soil particle size present in the sample that was used to generate the reference soil water retention curve. In the PHI program, the input data correspond to the absolute percentages of each granulometric fraction in the sample and its respective diameter in the phi scale $[\varphi=-\log 2 \mathrm{D}$ $(\mathrm{mm})]$. Diameter classes were transformed to a phi scale whereby $\phi$ from $\leq 2$ to $>1 \mathrm{~mm}$ led to $\varphi$ from $\leq-1$ to $>0$; $\phi$ from $\leq 1$ to $>0.5 \mathrm{~mm}$ to $\varphi$ from $\leq 0$ to $>1 ; \phi$ from $\leq 0.5$ to $>0.25 \mathrm{~mm}$ to $\varphi$ from $\leq 1$ to $>2 ; \phi$ from $\leq 0.25$ to $>$ $0.105 \mathrm{~mm}$ to $\varphi$ from $\leq 2$ to $>3.32 ; \phi$ from $\leq 0.105$ to $>0.053 \mathrm{~mm}$ to $\varphi$ from $\leq 3.32$ to $>4.32 ; \phi$ from $\leq 0.053 \mathrm{~mm}$ to $\varphi$ from $\leq 4.32$.

The experiment had two controls, one as a reference for biofertilizer rates and the other as a reference for the soil cultivated. Analysis of variance was performed by F test considering five treatments and four replications. The comparison the means of the other treatments (biofertilizer 0,20,40 and 60\%) in relation to soil under forest was performed by Dunnett test at 0.005 probability level. With respect to four methods to obtain the $S_{\text {relative-index }}$ 
(ADFE, with dispersion in water and with addition of $1 \mathrm{~N}$ sodium hydroxide - with and without washing) the means were compared by Tukey test at 0.005 probability level.

The data of soil bulk density and total porosity that were obtained using the five samples collected in the layer of $0-10 \mathrm{~cm}$, besides those referring to the treatments, were considered along with those obtained also in the same layer considering the treatments, thus totaling data of 18 samples (from 25 data seven were discarded because were identified as outliers). Then, regression and correlation analyses were performed between the $S_{\text {relative }}$-index (dependent variable) — obtained using ADFE, with dispersion in water and with addition of $1 \mathrm{~N}$ sodium hydroxide (with and without washing) - and each one of the two previously cited attributes (independent variable). Student's t-test at $20 \%$ significance level was applied to the obtained lines to verify the slope and intercept.

\section{Results and Discussion}

As to the S-index (Figure 1), it was observed that the application of biofertilizer did not significantly alter soil quality except in the $0-10 \mathrm{~cm}$ and $10-20 \mathrm{~cm}$ layers with the $40 \%$ concentration. In the $20-30 \mathrm{~cm}$ layer the soil quality was significantly worsened without the addition of the biofertilizer. Additionally, the values in all treatments are above 0.035 , considered by Dexter (2004a) as a limit to separate a soil with good physical quality, i.e., with adequate structural conditions, proper physical functioning as a component of the environment with specific functions and, consequently, with lower restriction to the root growth of the crops (Maia, 2011; Streck et al., 2008).

It should be pointed out that the establishment of fixed values as indicators for the classification of such a complex mechanism such as soil physical quality, for example 0.35 to S-index, has been a constant criticism of this indicator (Jong van Lier, 2014). This fact leads to soil quality indexes being relativized considering a soil reference, from which the changes can be measured.

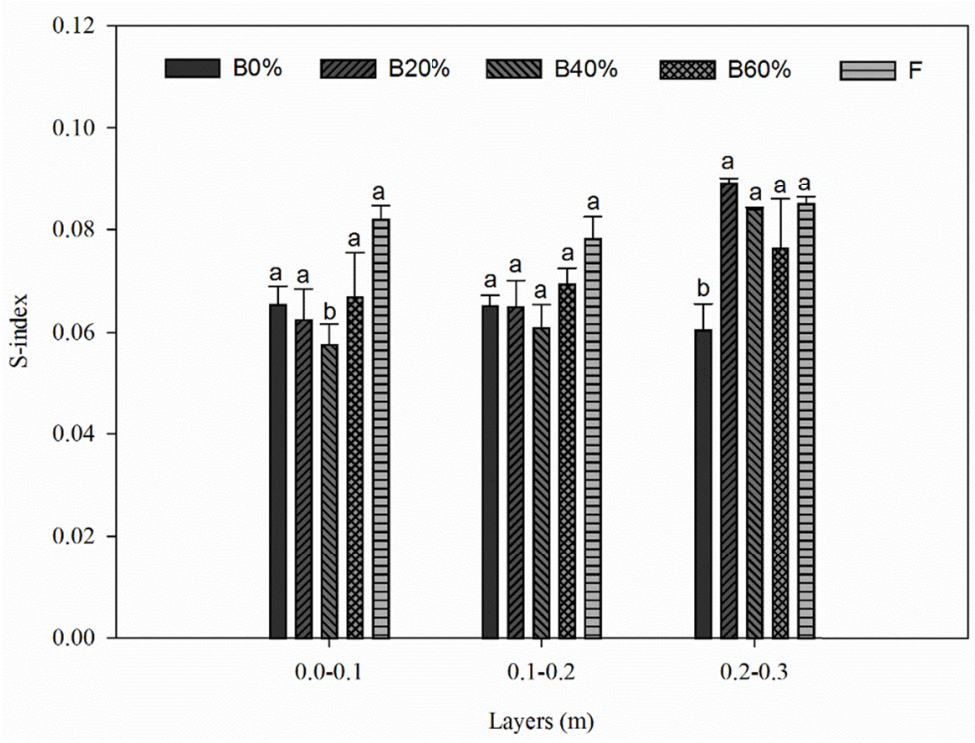

Figure 1. S-index for areas under fig cultivation and forest in layers of $0-10 \mathrm{~cm}, 10-20 \mathrm{~cm}$ and $20-30 \mathrm{~cm}(\mathrm{~B} 0 \%$ Control; B20\% - Biofertilizer 20\%; B40\% - Biofertilizer 40\%; B60\% - Biofertilizer 60\%; F - Forest). Means

followed by the same letter in a layer do not differ statistically based on Dunnett test at $5 \%$ of probability

According to Figure 2, it is possible to observe the distribution of the different granulometric fractions in the materials that originated from reference curves, which resulted in the different values of S-index and, consequently, of $S_{\text {relative }}$-index in the layer of 0-10 cm. The concentrations of the fractions in certain classes of $\varphi$ (phi) differed according to the treatment to which the material was subjected. In the method of ADFE, the highest relative amounts of material were concentrated in the fractions of greater diameter (coarser material); on the other hand, in the method with material dispersed in water, the highest concentrations occurred in the fractions of smaller diameters (finer material). The results certainly evidenced that the dispersion process, which acts in the disaggregation of the particles, increased the number of fractions with smaller diameter and, therefore, when accommodated, result in porosity as close as possible to the textural porosity. 


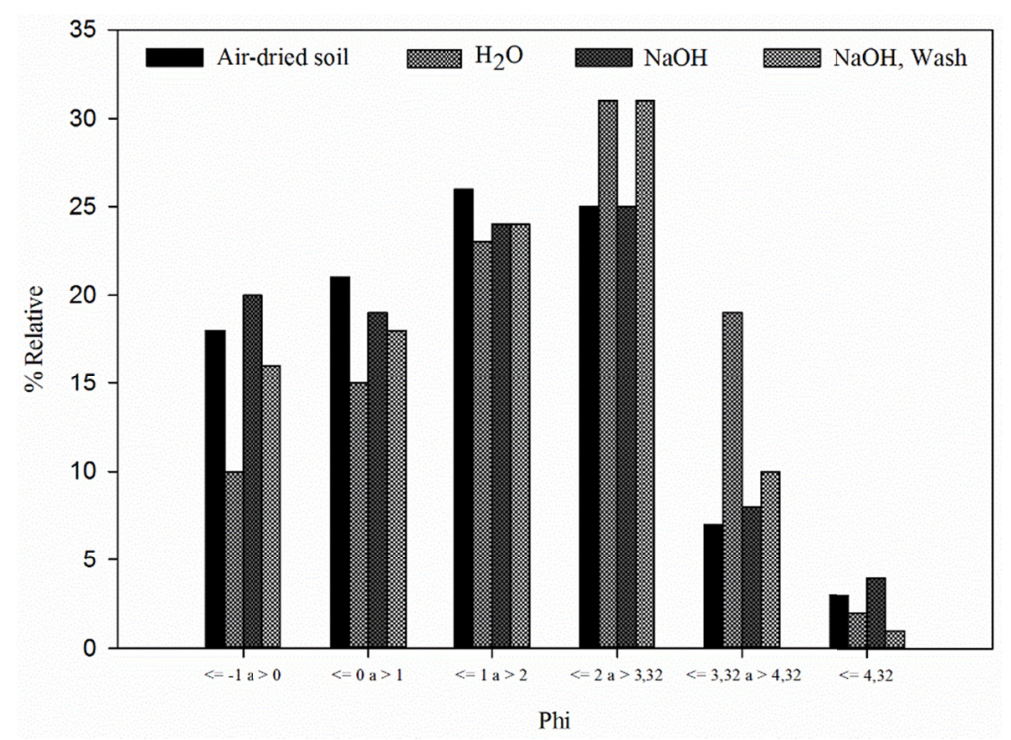

Figure 2. Histogram of particle size distribution in the material for the construction of standard curve reference

All the materials for the determination of the reference curves for the different methods were classified as poorly selected (Folk \& Ward, 1957), for showing different particle sizes inside the defined classes $(1 \mathrm{~mm} ; 0.5 \mathrm{~mm} ; 0.25$ $\mathrm{mm} ; 0.105 \mathrm{~mm}, 0.053 \mathrm{~mm})$, totaling six classes of size ( $\leq 2 \mathrm{~mm}$ to $>1 \mathrm{~mm} ; \leq 1 \mathrm{~mm}$ to $>0.5 \mathrm{~mm} ; \leq 0.5 \mathrm{~mm}$ to $>$ $0.25 \mathrm{~mm} ; \leq 0.25 \mathrm{~mm}$ to $>0.105 \mathrm{~mm} ; \leq 0.105 \mathrm{~mm}$ to $>0.053 \mathrm{~mm} ; \leq 0.053 \mathrm{~mm})$, thus demonstrating that the process of dispersion did not act to homogenize the size of the particles, but to disperse them, individualizing them.

Methods used to estimate $S_{\text {relative }}$-index show significant difference revealed by Tukey test at 0.05 probability level (Figure 3). The treatment with dispersion in water showed higher sensitivity in the detection of variations associated with soil structure; therefore, in order to obtain reliable results using the $S_{\text {relative-index as an evaluator of }}$ soil physical quality, one should use the reference curve obtained through soil dispersion in water, because this procedure leads to better individualization of soil particles (Figure 2). It was been proven that, through the method using ADFE, the magnitude of the variations in soil structure cannot be fully measured, since the microstructures in the material to obtain the reference curve- because the particles are not individualized - contribute to

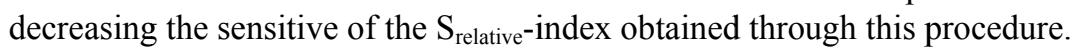

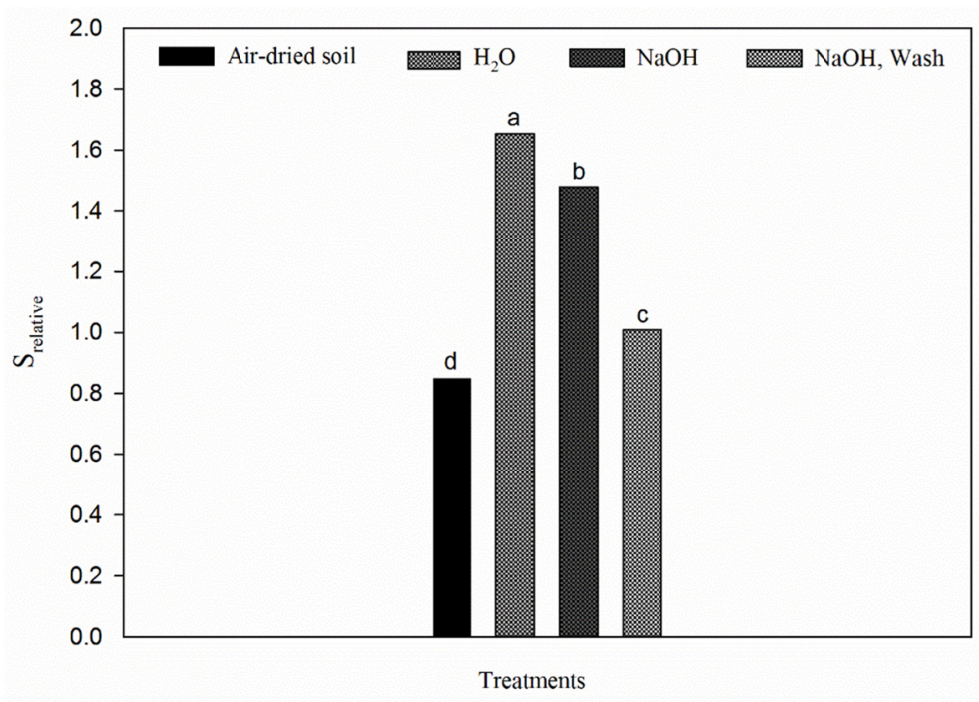

Figure 3. $\mathrm{S}_{\text {relative }}$-index values based on methods of construction of the standard curve reference. Means followed by the same letter do not differ based on Tukey test at $5 \%$ of probability 


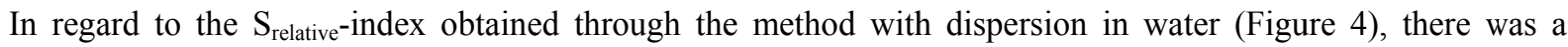
significant difference between the treatments with biofertilizer $40 \%$ and control in relation to the forest, in the layers of $0-0.1 \mathrm{~m}, 0.1-0.2 \mathrm{~m}$ and $0.2-0.3 \mathrm{~m}$, being different from the results obtained by the $\mathrm{S}$ index, thus

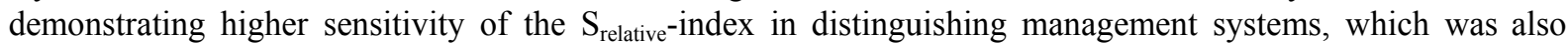
observed by Freire (2012) and Alves (2013). In all treatments, the observed values of $\mathrm{S}_{\text {relative }}$-index remained above 1 indicating that soil structure was improved in relation to the reference situation.

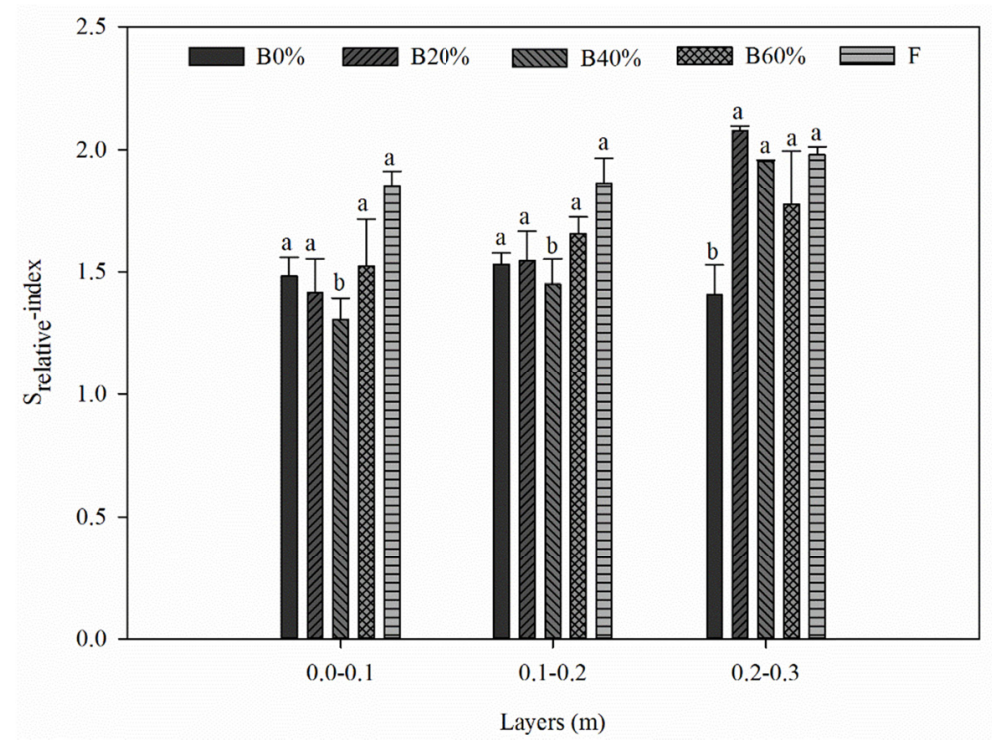

Figure 4. $\mathrm{S}_{\text {relative }}$-index for areas under fig cultivation and forest in layers of 0-10 cm, 10-20 cm and 20-30 cm (B0\% - Control; B20\% - 20\% of biofertilizer; B40\% - 40\% of biofertilizer; B60\% - 60\% of biofertilizer; F Forest). Means followed by the same letter in the layer do not differ based on Dunnett test at $5 \%$ of probability

In the layers of $0-10 \mathrm{~cm}$ and $10-20 \mathrm{~cm}$, the soil under application of biofertilizer $40 \%$ showed reductions of approximately $29 \%$ and $22 \%$ in its structural quality, respectively; in the layer of $20-30 \mathrm{~cm}$, the control has structure with quality $29 \%$ inferior in relation to the system taken as reference, the forest.

Regarding the analyses of correlation and regression between $\mathrm{S}_{\text {relative-index values obtained through different }}$ procedures and attributes of the soil porous fraction, there was a good relationship with soil bulk density (Figure 5), total porosity (Figure 6) and S index (Figure 7), which was evidenced by the significant correlation coefficients based on Student's t-test at 0.01 probability level. The regression equations had angular coefficient (b) different from zero i.e. the lines were not parallel to the $\mathrm{x}$-axis and, therefore, variations in any of these attributes cause a change in the $\mathrm{S}_{\text {relative-index value. }}$ 


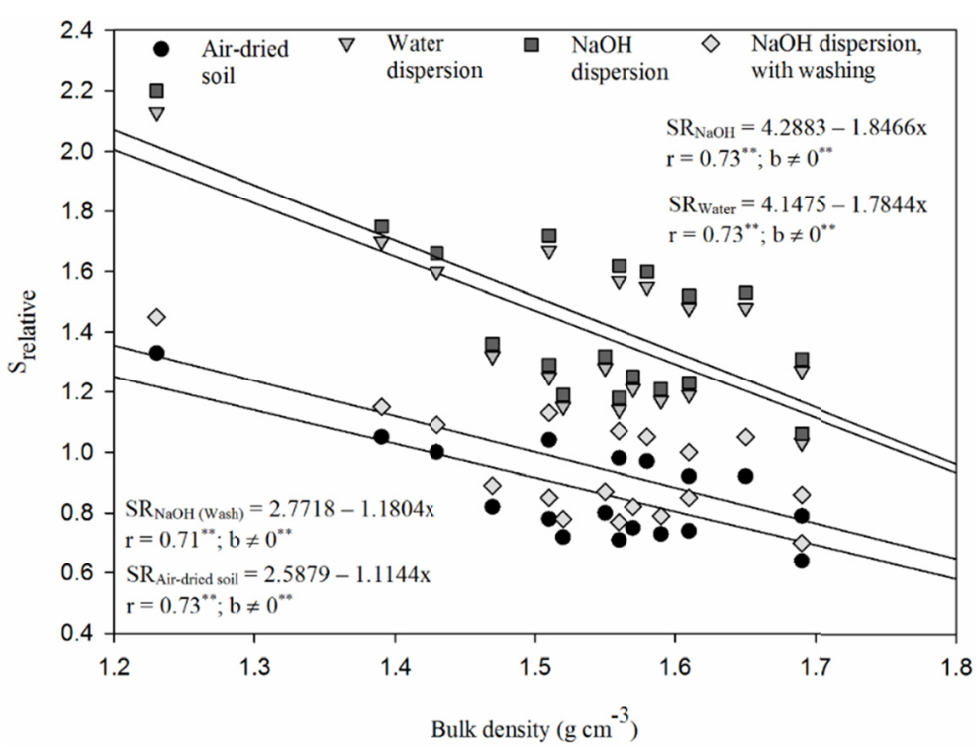

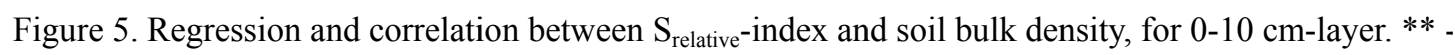
significant based on Student's $t$ test at $1 \%$ of probability



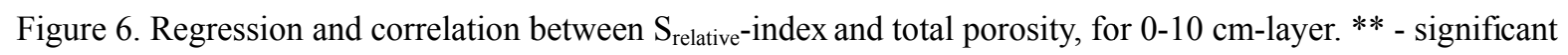
based on Student's t test at 1\% of probability 


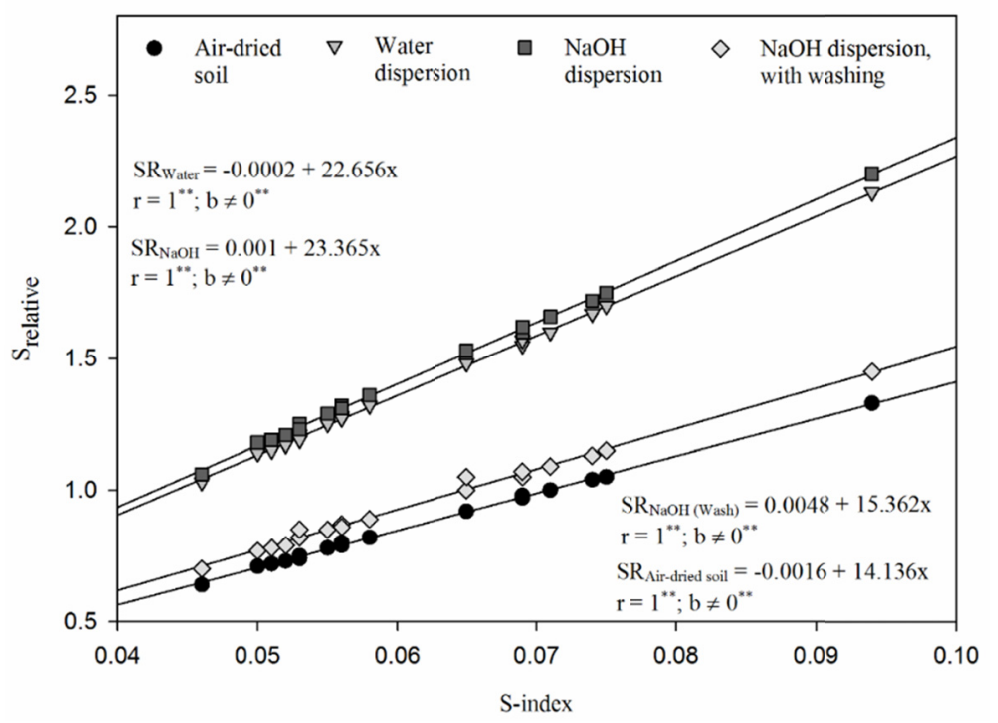

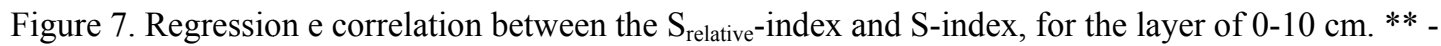
significant based on Student's t test at $1 \%$ of probability

The variation in soil bulk density and total porosity explained about $73 \%$ of the variation in $\mathrm{S}_{\text {relative }}$ indices in all analyzed treatments considering $\mathrm{S}_{\text {relative }}$-index obtained using ADFE, dispersion in water and with addition of $1 \mathrm{~N}$

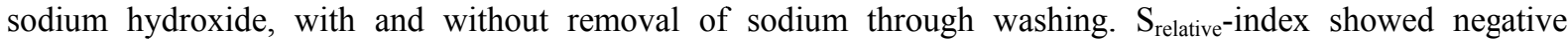
relationship with soil bulk density, which meant that increases in the values of this attribute corresponded to reduction in $\mathrm{S}_{\text {relative }}$-index values. This index is positively correlated to soil porosity, indicating that the increase in the amount of soil pores represented an increment in the value of $S_{\text {relative-index. Results reported by Alves (2013) }}$ corroborated those of the present study. As predicted, since they are dependent, the $\mathrm{S}$ index has perfect correlation with $\mathrm{S}_{\text {relative-index (Figure 7). }}$

According to the analysis of the parallelism of the lines and that of the intercepts (Table 3), using Student's t-test at

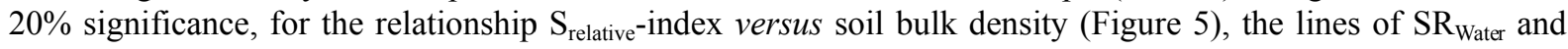
$\mathrm{SR}_{\mathrm{NaOH}}$ indicated a higher sensitivity, for they showed different slopes compared to the others i.e. small variations in soil bulk density led to greater variations in the values of $S_{\text {relative }}$-index. Both lines mentioned, were classified as parallel for they had the same intercept and slope. The meaning of this behavior is that it is possible to use either of these two mathematical functions associated with them to represent the relationship between both variables. As to Figure 6, the lines also showed differences and the $\mathrm{SR}_{\mathrm{NaOH}}$ line differed with respect to the slope of the lines of $\mathrm{SR}_{\mathrm{ADFE}}$ and $\mathrm{SR}_{\mathrm{NaOH}}$ (washing), but was parallel to $\mathrm{SR}_{\text {Water, }}$, with all lines showing the same intercept.

Table 3. Analysis of line parallelism and intercept using Student's t-test at 20\% probability

\begin{tabular}{|c|c|c|c|c|c|}
\hline \multirow{2}{*}{ Attributes } & \multirow{2}{*}{ Methods } & \multicolumn{2}{|c|}{ Slope } & \multicolumn{2}{|c|}{ Intercept } \\
\hline & & t observed & t table & t observed & $\mathrm{t}$ table \\
\hline \multirow{6}{*}{$\begin{array}{l}\mathrm{S}_{\text {relative }} \text {-index versus } \\
\text { bulk density }\end{array}$} & $\mathrm{SR}_{\text {Air-dread soil }} v s \mathrm{SR}_{\text {Water }}$ & 1.673 & 1.306 & 0.328 & 1.306 \\
\hline & $\mathrm{SR}_{\text {Air-dread soil }}$ vs $\mathrm{SR}_{\mathrm{NaOH}}$ & 1.457 & 1.306 & 0.357 & 1.306 \\
\hline & $\mathrm{SR}_{\text {Air-dread soil }} v s \mathrm{SR}_{\mathrm{NaOH} \text { (Wash) }}$ & 0.168 & 1.306 & 0.039 & 1.306 \\
\hline & $\mathrm{SR}_{\text {Water }}$ vs $\mathrm{SR}_{\mathrm{NaOH}}$ & 0.188 & 1.306 & 0.030 & 1.306 \\
\hline & $\mathrm{SR}_{\text {Water }} v s \mathrm{SR}_{\mathrm{NaOH} \text { (Wash) }}$ & 1.430 & 1.306 & 0.289 & 1.306 \\
\hline & $\mathrm{SR}_{\mathrm{NaOH}}$ vs $\mathrm{SR}_{\mathrm{NaOH}}$ (Wash) & 1.281 & 1.306 & 0.289 & 1.306 \\
\hline \multirow{6}{*}{$\begin{array}{l}\mathrm{S}_{\text {relative }} \text {-index versus } \\
\text { total porosity }\end{array}$} & $\mathrm{SR}_{\text {Air-dread soil }}$ vs $\mathrm{SR}_{\text {Water }}$ & 0.760 & 1.306 & 0.057 & 1.306 \\
\hline & $\mathrm{SR}_{\text {Air-dread soil }}$ vs $\mathrm{SR}_{\mathrm{NaOH}}$ & 1.482 & 1.306 & 0.063 & 1.306 \\
\hline & $\mathrm{SR}_{\text {Air-dread soil }}$ vs $\mathrm{SR}_{\mathrm{NaOH} \text { (Wash) }}$ & 0.157 & 1.306 & 0.006 & 1.306 \\
\hline & $\mathrm{SR}_{\text {Water }}$ vs $\mathrm{SR}_{\mathrm{NaOH}}$ & 0.064 & 1.306 & 0.006 & 1.306 \\
\hline & $\mathrm{SR}_{\text {Water }} v s \mathrm{SR}_{\mathrm{NaOH} \text { (Wash) }}$ & 0.684 & 1.306 & 0.063 & 1.306 \\
\hline & $\mathrm{SR}_{\mathrm{NaOH}} v s \mathrm{SR}_{\mathrm{NaOH} \text { (Wash) }}$ & 1.315 & 1.306 & 0.063 & 1.306 \\
\hline
\end{tabular}


Given these results, with significant differences between the lines for all analyzed relationships and greater sensitivities observed for $\mathrm{SR}_{\text {Water }}$ and $\mathrm{SR}_{\mathrm{NaOH}}$, the fact that obtaining $\mathrm{SR}_{\text {Water }}$ is simpler suggests that this indicator is the one that must be used to evaluate soil structural quality.

\section{Conclusions}

$\mathrm{S}$ and $\mathrm{S}_{\text {relative }}$ indices were sensitive to soil physical alterations caused by the application of the biofertilizer. Srelative-index was sensitive to variation in soil bulk density and total porosity. The $\mathrm{S}_{\text {relative-index obtained from }}$ the method of soil dispersion in water is more sensitive to soil physical alterations in comparison to $S_{\text {relative }}$-index obtained through air-dried fine earth.

\section{References}

Alencar, T. L. (2014). Alterações físicas em um Cambissolo tratado com biofertilizante: indicadores de qualidade e refinamento do método de avaliação pelo $S_{\text {relativo }}$ (Dissertation, Federal University of Ceará, Fortaleza, Brazil). Retrieved from http:/www.ppgsolos.ufc.br/images/DISSERTAÇÃOTHIAGOLEITEDE ALENCAR.compressed.pdf

Alves, C. V. O. (2013). Índice Srelativo como avaliador da qualidade física e sua relação com atributos da fração porosa de um Cambissolo (Dissertation, Federal University of Ceará, Fortaleza, Brazil). Retrieved from http://www.teses.ufc.br/tde_busca/arquivo.php?codArquivo=10214

Armenise, E., Redmile-Gordon, M. A., Stellacci, A. M., Ciccarese, A., \& Rubino, P. (2013). Developing a soil quality index to compare soil fitness for agricultural use under different managements in the Mediterranean environment. Soil \& Tillage Research, 130, 91-98. https://doi.org/10.1016/j.s till.2013.02.013

Arshad, M. A., \& Martin, S. (2002). Identifying critical limits for soil quality indicators in agro-ecosystems. Agriculture, Ecosystems \& Environment, 88, 153-160. https://doi.org/10.1016/S0167-8809(01)00252-3

Assis Júnior, R. N., Mota, J. C. A., Freire, A. G., \& Alencar, T. L. (2016). Pore network of a Cambisol in the Apodi Plateau, Brazil: Soil physical quality indicators with suggestion of relativization to S-index. Pesquisa Agropecuária Brasileira, 51, 1575-1583. https://doi.org/10.1590/s0100-204x2016000900057

Blake, G. R., \& Hartge, K. H. (1986a). Bulk density. In A. Klute (Ed.), Methods of soil analysis (2nd ed.). Soil Science Society of American (Pt 1, pp. 363-75, Agronomy Monography, 9). Madison: American Society of Agronomy.

Blake, G. R., \& Hartge, K. H. (1986b). Particle density. In A. Klute (Ed.), Methods of soil analysis (2nd ed.). Soil Science Society of American (Pt 1, pp. 377-82, Agronomy Monography, 9). Madison: American Society of Agronomy.

Dexter, A. R. (2004). Soil physical quality: Part I. Theory, effects of soil texture, density, and organic matter, and effects on root growth. Geoderma, 120, 201-214. https://doi.org/10.1016/j.geoderma.2003.09.004

Dourado-Neto, D., Nielsen, D. R., Hopmans, J. W., Reichardt, K., \& Bacchi, O. O. S. (2000). Software to model soil water retention curves (SWRC, Version 2.00). Scientia Agricola, 57, 191-192. https://doi.org/ 10.1590/S0103-90162000000100031

Embrapa (Empresa Brasileira de Pesquisa Agropecuária). (2013). Sistema Brasileiro de Classificação de Solos (3rd ed., p. 353). Embrapa, Brasília.

Folk, R. L., \& Ward, W. C. (1957). Brazos river bar: A study on the significance of grain-size parameters. Journal of Sedimentary Petrology, 27, 3-26. https://doi.org/10.1306/74D70646-2B21-11D7-8648000102 C1865D

Freire, A. G. (2012). Índices de qualidade fisica para um Cambissolo em sistemas de manejo (Dissertation, Federal University of Ceará, Fortaleza, Brazil). Retrieved from http:/www.teses.ufc.br/tde_busca/arquivo. php? codArquivo $=8141$

Gee, G. W., \& Bauder, J. W. (1986). Particle-size analysis. In A. Klute (Ed.), Methods of soil analysis (2nd ed.). Soil Science Society of America (Pt 1, pp. 83-411, Agronomy Monography, 9). Madison: American Society of Agronomy,

Jong van Lier, Q. (2014). Revisiting the s-index for soil physical quality and its use in Brazil. Revista Brasileira de Ciência do Solo, 38, 1-10. https://doi.org/10.1590/S0100-06832014000100001

Jong van Lier, Q., \& Vidal-Torrado, P. (1992). PHI: Programa de microcomputador para análise estatística da granulometria de sedimentos. Revista Brasileira de Ciência do Solo, 16, 277-281. 
Klute, A. (1986). Water retention: Laboratory methods. In A. Klute (Ed.), Methods of Soil Analysis, Physical and Mineralogical Methods. Soil Science Society of America (Pt 1, pp. 635-662, Agronomy Monography, 9). Madison: American Society of Agronomy.

Larson, W. E., \& Pierce, F. J. (1994). The dynamics of soil quality as a measure of sustainable management. In J. W. Doran, D. C. Coleman, D. F. Bezdicek, \& B. A. Stewart (Eds.), Defining soil quality for the sustainable environment. Soil Science Society of America (Publication Special, 35). Madison: American Society of Agronomy.

Maia, C. E. (2011). Índice S para avaliação da qualidade física de solos. Revista Brasileira de Ciência do Solo, 35 , 1959-1965. https://doi.org/10.1590/S0100-06832011000600012

Neves, C. M. N. N., Silva, M. L. N., Curi, N., Cardoso, E. L., Macedo, R. L. G., Ferreira, M. M., \& Souza, F. S. (2007). Atributos indicadores da qualidade do solo em sistema agrossilvopastoril no noroeste do Estado de Minas Gerais. Scientia Forestalis, 74, 45-53.

Obade, V. P., \& Lal, R. (2016a). A standardized soil quality index for diverse field conditions. Science of the Total Environment, 541, 424-434. https://doi.org/10.1016/j.scitotenv.2015.09.096

Obade, V. P., \& Lal, R. (2016b). Towards a standard technique for soil quality assessment. Geoderma, 265, 96-102. https://doi.org/10.1016/j.geoderma.2015.11.023

Ripoche, A., Celette, F., Cinna, J. P., \& Gary, C. (2010). Design of intercrop management plans to fulfil production and environmental objectives in vineyards. European Journal of Agronomy, 32, 30-39. https://doi.org/10.1016/j.eja.2009.05.005

Streck, C. A. (2007). Índice S e fluxo de água e ar em solos do Sul do Brasil [tese]. Santa Maria: Universidade Federal de Santa Maria.

Van Genuchten, M. T. (1980). A closed-form equation for predicting the hydraulic conductivity of unsaturated soils. Soil Science Society of America Journal, 44, 892-898. https://doi.org/10.2136/sssaj1980.03615995004 400050002x

Villamil, M. B., Miguez, F. E., \& Bollero, G. A. (2008). Multivariate Analysis and Visualization of Soil Quality Data for No-Till Systems. Journal of Environmental Quality, 37, 2063-2069. https://doi.org/10.2134/ jeq2007.0349

\section{Copyrights}

Copyright for this article is retained by the author(s), with first publication rights granted to the journal.

This is an open-access article distributed under the terms and conditions of the Creative Commons Attribution license (http://creativecommons.org/licenses/by/4.0/). 